\title{
Who are the targets of youth programs: results of a capacity building exercise in Ethiopia
}

\author{
Tekle-Ab Mekbib ${ }^{1}$, Annabel Erulkar², Fekerte Belete ${ }^{3}$
}

\begin{abstract}
Few adolescent reproductive health programs monitor who they reach. Staff from thirteen peer education and youth club programs recorded details of their contacts. The majority of beneficiaries were boys (58 percent) and were inschool (78 percent). A considerable percentage were outside the target age. Programs should monitor who they are reaching and who they are not, and should target underserved youth, especially girls, and those who are younger, outof school, and married. [Ethiop.J.Health Dev. 2005;19(1):60-62]
\end{abstract}

\section{Introduction}

In Ethiopia, a number of organizations have been engaged in adolescent reproductive health activities, with the most popular approaches being school-based programs, youth centers, youth-friendly health services, and peer-education. At the same time, there is rarely understanding of which subgroups of youth are reached by programs and which are left out. Programs may fail to reach certain groups of adolescents because they operate on incorrect assumptions about adolescents (1). There is a widespread misconception that adolescents are largely in school and living with parents.

In Ethiopia, 18 percent of adolescents aged 10 to 14 live with no parent, with the figure climbing to 30 percent among urban girls. Only 17 percent of rural girls are enrolled in school (2). Among urban adolescents, 66 percent of boys and 52 percent of girls are attending school (3). Moreover, most Ethiopian adolescents reside in rural areas, with 86 percent of youth aged 10 to 14 , and 80 percent of youth 15 to 19 living in rural areas (2). This has far reaching implications for youth programs, especially those that emphasize activities in schools.

While large investments in research are not always feasible, there are simple monitoring tools that can contribute to improving the quality and coverage of programs. This paper describes a capacity building exercise among youth serving NGOs and demonstrates how simple "low-tech" monitoring tools assisted organizations to undertake a process of self-assessment that led to rethinking strategies to reach vulnerable youth.

\footnotetext{
Methodology

This study was conducted in 2003 and was a joint undertaking between the Population Council, PACT, DSW, FGAE and 13 youth serving organizations from Addis Ababa, Amhara, Oromia and SNNPR. These organizations were primarily engaged in urban based peer education and youth clubs and target young people aged 10 to 24. All but one of the organizations operated in a variety of settings, both in schools as well as in the
}

community, in order to reach young people. In addition, all organizations targeted both in and out of school youth, except for one that focused on those who are out of school.

An activity register was developed in order to record the daily activities of peer educators and youth club leaders, who filled out the register in the context of their everyday activities, for every contact that they made, for a period of two months. A follow-up meeting was held with peer educators to discuss the pattern of service provision.

\section{Results}

Over 10,000 contacts were recorded during the data collection period. The average number of contacts per provider per week ranged from 21 to 80 . Ten out of thirteen organizations were serving more boys than girls, with 58 percent of contacts being male. Moreover, older adolescents, especially older boys were the main beneficiaries. While only 22 percent of beneficiaries were aged 10 to 14,64 percent were aged 15 to 24 . In addition 14 percent of contacts were outside the age range for the organizations, over the age of 24. Among beneficiaries aged 10 to 24,78 percent were in school, with three programs having over 90 percent of beneficiaries in school (Table 1).

While 69 percent of contacts included HIV information, only 20 percent included information on condoms.

\section{Discussion}

Most programs are more effective at reaching older, inschool adolescents, and are perhaps neglecting the more vulnerable groups. The excess of in-school beneficiaries is not surprising given that the school is a convenient setting to reach large numbers of young people. All participating programs were urban-based programs while an estimated 83 percent of youth reside in rural areas (2). Programs need to design innovative ways of reaching out-of-school populations, as well as girls and very

\footnotetext{
${ }^{1}$ Population Council, P.O. Box 33998, Telephone 526574, E-mail: mekbibt@telecom.net.et, Addis Ababa, Ethiopia;

${ }^{2}$ Population Council, Accra, Ghana, ${ }^{3}$ PACT-Ethiopia
} 
Table 1: Profile of beneficiaries of peer educators and youth clubs, by sex, school status, and age group

\begin{tabular}{|c|c|c|c|c|c|c|c|c|c|}
\hline \multirow[b]{2}{*}{$\begin{array}{l}\text { Name of } \\
\text { Organization }\end{array}$} & \multirow[b]{2}{*}{$\begin{array}{l}\text { Ave. No. } \\
\text { of } \\
\text { contacts/ } \\
\text { week }\end{array}$} & \multicolumn{2}{|c|}{ Sex } & \multicolumn{2}{|c|}{ School Status } & \multicolumn{4}{|c|}{ Age group } \\
\hline & & $\begin{array}{l}\text { Percent } \\
\text { females }\end{array}$ & $\begin{array}{l}\text { Percent } \\
\text { males }\end{array}$ & $\begin{array}{c}\text { In } \\
\text { School }\end{array}$ & $\begin{array}{l}\text { Out of } \\
\text { School }\end{array}$ & $\begin{array}{c}10 \text { to } \\
14\end{array}$ & $\begin{array}{c}15 \text { to } \\
19\end{array}$ & $\begin{array}{l}20 \text { to } \\
24\end{array}$ & $\begin{array}{l}\text { Over } \\
\text { age } \\
(25+)\end{array}$ \\
\hline $\begin{array}{l}\text { All } \\
\text { organizations } \\
(n=10,873)\end{array}$ & 51 & 42 & 58 & 78 & 22 & 22 & 45 & 19 & 14 \\
\hline $\begin{array}{l}\text { BICDO } \\
(n=1212)\end{array}$ & 67 & 40 & 60 & 77 & 23 & 27 & 37 & 16 & 20 \\
\hline $\begin{array}{l}\text { CHADET } \\
(n=953)\end{array}$ & 53 & 47 & 53 & 71 & 29 & 22 & 35 & 18 & 25 \\
\hline DAO $(n=1445)$ & 80 & 30 & 70 & 98 & 2 & 42 & 48 & 3 & 7 \\
\hline $\begin{array}{l}\text { ISAPSO } \\
(n=994)\end{array}$ & 55 & 35 & 65 & 93 & 7 & 52 & 43 & 4 & 2 \\
\hline $\begin{array}{l}\text { PADET } \\
(n=125)\end{array}$ & 21 & 16 & 84 & 63 & 37 & 26 & 26 & 18 & 30 \\
\hline $\begin{array}{l}\text { SYGA DB } \\
(n=395)\end{array}$ & 33 & 56 & 44 & 57 & 43 & 6 & 35 & 44 & 15 \\
\hline $\begin{array}{l}\text { SYGA NAZ } \\
(n=1142)\end{array}$ & 63 & 37 & 63 & 91 & 9 & 15 & 73 & 9 & 3 \\
\hline $\begin{array}{l}\text { FGAE AA } \\
(n=457)\end{array}$ & 38 & 70 & 30 & 52 & 48 & 3 & 42 & 33 & 22 \\
\hline $\begin{array}{l}\text { FGAE AWA } \\
(n=1081)\end{array}$ & 60 & 44 & 56 & 80 & 20 & 22 & 38 & 26 & 14 \\
\hline $\begin{array}{l}\text { FGAE NAZ } \\
(n=1094)\end{array}$ & 61 & 56 & 44 & 63 & 37 & 14 & 55 & 25 & 6 \\
\hline $\begin{array}{l}\text { HIWOT AA } \\
(n=655)\end{array}$ & 36 & 41 & 59 & 74 & 26 & 5 & 60 & 27 & 8 \\
\hline $\begin{array}{l}\text { TAMRA SHA } \\
(\mathrm{n}=541)\end{array}$ & 30 & 45 & 55 & 60 & 40 & 1 & 30 & 38 & 31 \\
\hline WSO (n=779) & 66 & 41 & 59 & 60 & 40 & 9 & 35 & 25 & 31 \\
\hline
\end{tabular}

young adolescents. During follow-up discussions with peer educators and youth club leaders, they emphasized the importance of monitoring their contacts and performance. As a simple, low cost management tool, the register highlighted the critical gaps in performance and helped them to be more efficient in targeting the most vulnerable adolescents. Existing programs need to strengthen systems for recording, analyzing and utilizing performance data for improving their programs.

The low percentage of contacts including information on condoms suggests that they may have stressed other topics such as transmission and abstinence. This tendency to avoid sensitive topics such as condoms is a common feature of many adolescent reproductive health programs (4).

\section{Acknowledgements}

The authors sincerely acknowledge the collaborating agencies namely, PACT-Ethiopia, DSW and the Family Guidance Association of Ethiopia (FGAE) for their interest and commitment they showed in this exercise. Judith Bruce provided guidance and encouragement throughout the exercise. Our thanks also go to peer service providers and youth club leaders for their dedication and excellent work in data collection.

\section{References}

1. Bruce J. Preparing the twenty first century generation of adults: policy and program perspectives. Population Council, Paper Commissioned by UNFPA. 2002. 
2. Facts about adolescents from the demographic and health survey: Statistical tables for program planning. Ethiopia 2000. Population Council 2002.

3. Central Statistical Authority (CSA) and ORC Macro. Ethiopia Demographic and Health Survey 2000. Addis Ababa, Ethiopia and Calverton, Maryland, USA: Central Statistical Authority and ORC Macro, 2001.
4. Senderowitz, J, A review of Program Approaches to Adolescent reproductive Health unpublished paper prepared for USAID and Population Technical Assistance Project, June, 2000. 
63 Ethiop.J.Health Dev.

Ethiop.J.Health Dev.2005; 19(1) 